\title{
THE MULTIELEMENT ANALYSIS OF THE APPLE PEEL USING ICP-OES METHOD
}

Branka T. Stojanović*, Snežana S. Mitić, Milan N. Mitić, Dušan Đ. Paunović, Biljana B. Arsić, Gordana S. Stojanović

(ORIGINAL SCIENTIFIC PAPER) UDC 546:582.711.714:543.4

Faculty of Sciences, Department of Chemistry, University of Niš, Niš, Serbia

The content of 21 elements in the peel of five apple cultivars was determined by using the inductively coupled plasma optical emission (ICP-OES) spectrometry. Among the major elements, the most abundant is $\mathrm{K}$, followed by $\mathrm{Ca}, \mathrm{P}$, $\mathrm{Na}$ and $\mathrm{Mg}$. The most abundant among the microelements are $\mathrm{Fe}, \mathrm{B}, \mathrm{Mn}, \mathrm{V}$, $\mathrm{Cu}$ and $\mathrm{Zn}$. In terms of heavy metals ( $\mathrm{As}, \mathrm{Cd}, \mathrm{Pb}$ ), it can be concluded that the concentrations of $\mathrm{As}, \mathrm{Cd}, \mathrm{Ni}$ and $\mathrm{Pb}$ are below permissible levels prescribed by national legislation and EU Directives. The results obtained from this study show that there are no health risks from the consumption of apples when compared with the levels stipulated by health authorities. Principal component analysis (PCA) was applied to classify the analyzed elements in five apple cultivars according to their contents.
Keywords: minerals, apple peel, ICP-OES, PCA.

\section{Introduction}

By increasing a clinical trial and epidemiological studies it has been established that a high dietary intake of fruits and vegetables is strongly associated with a reduced risk of developing some chronic diseases such as various types of cancer, a cardiovascular disease, type II diabetes and other degenerative or age-related diseases, which are the main causes of death in developed countries [1-2]. Main minerals and essential trace elements are very important in biological processes and play a vital role in normal growth and development, and have also been involved in the prevention of some chronic diseases [3].

There are micronutrients and minerals that concern us because of foods and food products consumption and/or occupational or residential exposure [4]. Some minerals include alkali and alkaline earth and heavy metal elements i.e. $\mathrm{Sb}, \mathrm{As}, \mathrm{Cd}, \mathrm{Cr}, \mathrm{Co}, \mathrm{Cu}, \mathrm{Fe}, \mathrm{Pb}, \mathrm{Mn}$, $\mathrm{Hg}$, Ni or Zn. Small amounts of the elements are common in our environment and diet and are actually necessary for good health, but large amounts of any of them may cause acute or chronic toxicity $[5,6]$. The toxicity of some heavy metals can reduce mental and central nervous functions and damage the blood composition, lungs, kidneys, liver, and other vital organs [7].

It is widely accepted that a dietary intake of selected fruits, especially those containing functional bioactives such as phenolic acids, tannins, flavonoids, and vitamins and essential minerals, is linked to the reduced prevalence of several chronic diseases [8-10]. The apple
(Malus domestica Borkh.), a member of the family Rosace$a e$, is one of the most frequently consumed fruits in many regions all over the world. The apple fruit has been identified as an excellent potential source of carbohydrates, minerals, dietary fiber and antioxidant phenolics [3-5]. Recent studies have revealed that the consumption of apple fruit and apple juice can provide antiproliferative, anticarcinogenicand anti-inflammatory health benefits and is strongly associated with lower incidence of lung cancer, viral diseases and cardiovascular disorders [8,10,13-15].

The apple peel, being a rich source of phenolics and dietary fiber, is also valued for its medicinal health functions $[12,13]$. The composition and distribution of nutrients and high-value components such as phenolics mainly depends upon genotypes, fruit tissue and maturity levels of fruits and, to a smaller extent on environmental aspects [16-19]. Unpeeled fruits possess higher contents of bioactive compounds as compared to the peeled ones [16]. The fruit peels, although medicinally important, are often discarded as agro-waste and have not yet received attention regarding their utilization for value-addition rather than being discarded. This might be due to the lack of commercial applications and consumer's unawareness of the benefits of consuming fruit peels. Interestingly, the peel fractions have been reported to have a higher antioxidant activity compared to the pulp fraction [20]. Gorinstein et al. [21] reported that mineral and total phenolic contents in persimmon and

\footnotetext{
*Author address: Branka T. Stojanović, Faculty of Sciences and Mathematics, Department of Chemistry, University of Niš, 33 Višegradska Street, 18000 Niš, Serbia

E-mail: brankastojanovic81@gmail.com

The manuscript received: October, 16, 2014.

Paper accepted: November, 20, 2014.
} 
apple peel were significantly higher compared to those in the pulp. Similarly, Loentowiczet al. [15] reported that apple and pear peel extracts exhibited a better potential as natural antioxidant supplements than the pulp extract.

Several methods for the determination of trace metals have been commonly conducted by flame atomic absorption spectrometry (FAAS) [22], graphite furnace atomic absorption spectrometry (GFAAS) [23], inductively coupled plasma-atomic/optical emission spectroscopy (ICP-AES/OES) [24-26] or inductively coupled plasmamass spectrometry.

Inductively coupled plasma optical emission spectrometry (ICP-OES) has proved to be a rapid and accurate technique for the determination of minor and major element contents in fruits [27]. ICP-OES is attractive for trace analysis, owing to the satisfactory sensitivity coupled with the advantage of simultaneous determinations of several metals at different spectral lines. ICP-OES and exploratory analysis were used for the determination of metals in apples and apple juice [28].

The aim of the present work was to determine minor and major element compositions in five apple cultivars as the basis for evaluating the health effect by metals through the apple consumption. Five apple cultivars purchased from the local market were analyzed for their minor and major element contents after the optimization and validating an appropriate analytical method using ICP-OES. The study is focused on those essential elements which can be easily determined by ICP-OES, namely $\mathrm{Ca}, \mathrm{K}, \mathrm{Mg}, \mathrm{Na}, \mathrm{P}, \mathrm{B}, \mathrm{Ba}, \mathrm{Co}, \mathrm{Cr}, \mathrm{Cu}, \mathrm{Fe}, \mathrm{Mn}, \mathrm{Ni}$, $\mathrm{Se}, \mathrm{Sr}, \mathrm{V}, \mathrm{Zn}, \mathrm{Al}, \mathrm{As}, \mathrm{Cd}$ and $\mathrm{Pb}$. By comparison, multielements classified as major, minor and nonessential elements were confined according to their amounts found as a residue and/or background contamination in the plant samples analyzed.

\section{Experimental part}

\section{Reagents}

Ultra-scientific (USA) ICP multi-element standard solutions of about $20.00 \pm 0.10 \mathrm{mg} / \mathrm{L}$ were used as a stock solution for calibration. The plastic containers used for storing the samples were cleaned to avoid contamination of the samples with traces of any metals. Containers were treated with $5 \%$ nitric acid and washed with ultrapure water $0.05 \mu \mathrm{Scm}^{-1}$ (MicroMed high purity water system, TKA Wasseraufbereitungssysteme $\mathrm{GmbH}$ ).

\section{Instrumentation}

All analyses were carried out on the iCAP 6000 inductively coupled plasma optical emission spectrometer (Thermo Scientific, Cambridge, UK) using an Echelle optical design and a charge injection device solid-state detector. The operating conditions are shown in Table 1.
Table 1. Operational parameters for ICP-OES measurements

\begin{tabular}{lc}
\hline Parameters & \\
\hline Flush pump rate & $100 \mathrm{rpm}$ \\
Analysis pump rate & $50 \mathrm{rpm}$ \\
RF power & $1150 \mathrm{~W}$ \\
Nebulizer gas & $0.7 \mathrm{Lmin}^{-1}$ \\
Coolant gas flow & $12 \mathrm{Lmin}^{-1}$ \\
Auxiliary gas flow & $0.5 \mathrm{Lmin}^{-1}$ \\
Plasma view & Dual mode \\
\hline
\end{tabular}

Dry ashing method was carried out in a VIMS electric (Serbia) furnace equipped with microprocessor program of temperature IVIGOS3123 $\left( \pm 1^{\circ} \mathrm{C}\right)$.

\section{Fruit Samples}

The apple $(n=5)$ samples were purchased from local markets in Niš. All apples analyzed are frequently consumed in Serbia.

\section{Procedures}

All apple samples were washed thoroughly and separately. Running tap water was employed to remove the dust and adhered particles and then the fruits were peeled off with a steel knife.The samples(apple peel) were later rinsed thrice with deionized water and subsequently dried in oven at $60-80{ }^{\circ} \mathrm{C}$ and then were homogenousin a blender. Prior to ICP-OES analysis, 10 $\mathrm{g}$ of homogenized apple peel samples was placed in porcelain vessels and heated for $12 \mathrm{~h}$. The vessels with the residue obtained after the vaporization of the water were ashed in a furnace for $24 \mathrm{~h}$. The furnace was programmed to raise the temperature starting from $50{ }^{\circ} \mathrm{C}$ to $450{ }^{\circ} \mathrm{C}$ in the first $16 \mathrm{~h}$, after which it was kept at constant $500{ }^{\circ} \mathrm{C}$ until the end of the process. The residues were treated with $1 \mathrm{~mL}$ conc. $\mathrm{HNO}_{3}$ and heated in a furnace again, until a complete mineralization of the sample was attained $(\sim 10 \mathrm{~h})$. The white obtained ashes were dissolved in $5 \%(\mathrm{v} / \mathrm{v}) \mathrm{HNO}_{3}$ to a total volume of $50 \mathrm{~mL}$. Table 2 lists the emission line selected for each of the elements, based upon tables of known interferences and baseline shifts and empirical observations made during the sample preparation [29]. Also, the correlation coefficients for the calibration straight line and the detection and determination are presented in Table 2. 
Table 2. Emission wavelength, linear working range, LOD, LOQ and correlation coefficient ( $r$ ) of the calibration for each mineral determination

\begin{tabular}{ccccc}
\hline Element & $\lambda(\mathrm{nm})$ & $\mathrm{LOD}(\mathrm{mg} / \mathrm{L})$ & $\mathrm{LOQ}(\mathrm{mg} / \mathrm{L})$ & $\mathrm{r}$ \\
\hline $\mathrm{Al}$ & 308.215 & 0.0045 & 0.0150 & 0.9841 \\
$\mathrm{As}$ & 189.042 & 0.0026 & 0.0086 & 0.9997 \\
$\mathrm{~B}$ & 249.773 & 0.2662 & 0.8875 & 0.9994 \\
$\mathrm{Ba}$ & 455.403 & 0.0001 & 0.0002 & 0.9999 \\
$\mathrm{Ca}$ & 393.366 & 0.0001 & 0.0004 & 0.9901 \\
$\mathrm{Cd}$ & 228.802 & 0.0002 & 0.0007 & 0.9999 \\
$\mathrm{Co}$ & 238.892 & 0.0011 & 0.0034 & 0.9999 \\
$\mathrm{Cr}$ & 283.563 & 0.0008 & 0.0026 & 0.9997 \\
$\mathrm{Cu}$ & 324.754 & 0.0006 & 0.0020 & 1.000 \\
$\mathrm{Fe}$ & 259.940 & 0.0006 & 0.0020 & 0.9957 \\
$\mathrm{~K}$ & 766.490 & 0.0017 & 0.0058 & 0.9979 \\
$\mathrm{Mg}$ & 279.553 & 0.0001 & 0.0006 & 0.9985 \\
$\mathrm{Mn}$ & 257.610 & 0.0001 & 0.0003 & 0.9999 \\
$\mathrm{Na}$ & 588.995 & 0.0008 & 0.0027 & 1.000 \\
$\mathrm{Ni}$ & 231.406 & 0.0006 & 0.0021 & 0.9999 \\
$\mathrm{P}$ & 213.618 & 0.0040 & 0.0134 & 0.9999 \\
$\mathrm{~Pb}$ & 220.353 & 0.0029 & 0.0097 & 0.9999 \\
$\mathrm{Se}$ & 196.090 & 0.0028 & 0.0094 & 0.9993 \\
$\mathrm{Sr}$ & 407.771 & 0.0001 & 0.0007 & 0.9995 \\
$\mathrm{~V}$ & 309.311 & 0.0008 & 0.0027 & 1.000 \\
$\mathrm{Zn}$ & 213.856 & 0.0001 & 0.0004 & 0.9998 \\
\hline
\end{tabular}

\section{Statistical Analysis}

Data were reported as mean \pm standard deviation (SD) for triplicate determinations.Principal component analysis (PCA) was used to evaluate the distribution of metals in the studied tissue [30, 31].

\section{Results and discussion}

Under the ICP-OES operating conditions for multielements measurement with their analytical lines used, differences in the suitable calibration ranges of these elements were established with $\mathrm{r} 2>0.984$. The limit of detection (LOD) and the limit of quantification (LOQ) for fifteen metals were determined by analyzing five portions of standard solutions simultaneously following the general procedure. The LOD values in $\mathrm{mgL}^{-1}$ defined as $3 \sigma$ where $\sigma$ is the standard deviation. The $L O Q$ values $(10 \sigma)$ were also determined to confine that the trace amount of some elements could be certainly detectable, although some of other elements had been tried to be analyzed as well.

Nutrient levels in foods are variable. In the case of fruits, mineral levels canbe affected by factors such as the variety of the produced item, harvest time, ripeness, climate, soil conditions including fertilizer application, and storage and marketing conditions. As biological materials, fruits are also the subject to random variation in the mineral content [32, 33].

Major minerals are those required in the amounts greater than $100 \mathrm{mg}$ per day and represent $1 \%$ or less of the bodyweight. Minor minerals are essential in much smaller amounts, less than $100 \mathrm{mg}$ per day, and make up less than $0.01 \%$ of the bodyweight [34].

In most of the elements evaluated, their content was significantly different depending on the cultivar and the fruit tissue evaluated. Apple peel fraction showed a higher significant mineral content, followed by the whole fruit (1.3 to 4.7 fold) and the pulp (1.7 to 8.8 fold) [21].

Recommended dietary allowances of the elements [35] (RDA (mgday $\left.{ }^{-1}\right)$ ) for some essential elements of human nutrition have been established, namely: Ca (1000 $\mathrm{mg}), \mathrm{Na} 1500 \mathrm{Cu}(1.2 \mathrm{mg}), \mathrm{Fe}(8 \mathrm{mg}), \mathrm{K}(4700 \mathrm{mg}), \mathrm{Mg}$ (400 mg), Co (not stated), Mn (2.3mg), P (1000mg), Mo $(0.05 \mathrm{mg})$ and $\mathrm{Zn}(11 \mathrm{mg})$.

The results of major elements for five varieties of the apple samples are shown in Table 3. For the major elements found in the apple peel samples the content of $\mathrm{K}$ is the highest, while those of $\mathrm{Ca}, \mathrm{Mg}$ and $\mathrm{Na}$ are lower. Average concentrations ( $\mathrm{mgkg}^{-1}$ of fresh weight) among these varieties were 173.3, 1516.1, 110.0, 128.1 and 169.3 for $\mathrm{Ca}, \mathrm{K}, \mathrm{Mg}, \mathrm{Na}$ and $\mathrm{P}$, respectively. At the consumer level, a high intake of $\mathrm{Ca}, \mathrm{Mg}$ and $\mathrm{K}$, together with a low $\mathrm{Na}$ intake, is associated with the protection against bone demineralization, arterial hypertension, insulin resistance, and overall cardiovascular risk [36]. Calcium is essential for all living organisms. The essential role is in blood clotting, muscle contraction, nerve transmission, and bone and tooth formation. Also, the importance of calcium in apple fruit is its role in contributing to the maintenance of the optimum quality during postharvest storage and fruit ripening. This role is seen directlyin the prevention of specific disorders such as bitter pit, and in relationships between calcium and more general quality properties such as flesh firmness [37]. Potassium is an important component of cell and body fluids and helps in controlling a heart rate and the blood pressure and thus counters the bad influences of sodium. Magnesium is required for processing ATP and for the stability of bones. Among the five apple cultivars, 'Idared' peel had the highestCa, $\mathrm{K}, \mathrm{Mg}$ and $\mathrm{P}$ content and 'Modi' peel had the highest Nacontent.

Table 3. Mean concentration ( $\mathrm{mgkg}^{-1}$ f.w.) and associated standard deviation (mean $\pm S D$ ) of major element in apple peel $(n=3)$.

\begin{tabular}{cccccc}
\hline Cultivar & $\mathrm{Ca}$ & $\mathrm{K}$ & $\mathrm{Mg}$ & $\mathrm{Na}$ & $\mathrm{P}$ \\
\hline Pink Lady & $143.23 \pm 1.41$ & $1509.26 \pm 11.21$ & $115.26 \pm 1.11$ & $126.44 \pm 1.13$ & $153.21 \pm 1.10$ \\
Red Delicious & $166.41 \pm 1.04$ & $1319.49 \pm 10.21$ & $98.73 \pm 1.00$ & $119.09 \pm 1.12$ & $198.12 \pm 1.31$ \\
Idared & $206.02 \pm 11.71$ & $1862.84 \pm 10.43$ & $116.69 \pm 1.10$ & $121.53 \pm 1.13$ & $213.20 \pm 1.50$ \\
Breburn & $148.85 \pm 1.44$ & $1236.02 \pm 9.01$ & $102.96 \pm 1.12$ & $129.47 \pm 1.14$ & $156.81 \pm 1.15$ \\
Modi & $202.14 \pm 1.81$ & $1653.08 \pm 10.07$ & $116.44 \pm 1.13$ & $143.76 \pm 1.15$ & $123.50 \pm 1.33$ \\
\hline
\end{tabular}


The results of minor elements are shown in Table 4. Minor elements can be classified as potentially toxic (Cd, $\mathrm{Pb}, \mathrm{Hg}$ ), probably essential ( $\mathrm{Ni}, \mathrm{Co}$ ) and essential ( $\mathrm{Cu}$, $\mathrm{Zn}, \mathrm{Fe}, \mathrm{Mn}$ )[38]. Essential minerals have several roles in human biochemistry and physiology. Many are cofactors for different enzymes and we are dependent on them for energy efficiency, fertility, mental stability and immunity. According to the data obtained, Fe has the highest concentration followed by $\mathrm{B}, \mathrm{Mn}, \mathrm{V}, \mathrm{Cu}, \mathrm{Zn}$ etc.
Se and Co have the lowest concentration. Some of these microelements ( $\mathrm{Fe}, \mathrm{Zn}, \mathrm{Cu}, \mathrm{Mn}$ ) are involved in many biochemical processes supporting life [39]. Among the five cultivars studied, 'Breburn' peel had the highest content of Fe; Red Delicious' peel had the highest content of Co; 'Pink Lady' had the highest content of Se; 'Modi' had the highest content of $\mathrm{B}, \mathrm{Ni}, \mathrm{Ba}$ and $\mathrm{Cr}$ and 'Idared' had the highest content of $\mathrm{V}, \mathrm{Cu}, \mathrm{Zn}, \mathrm{Mn}$ and $\mathrm{Sr}$.

Table 4. Mean concentration ( $\mathrm{mgkg}^{-1}$ f.w.) and associated standard deviation (mean \pm SD) of minor element in apple peel $(n=3)$.

\begin{tabular}{|c|c|c|c|c|c|c|c|c|c|c|c|c|c|c|c|}
\hline Cultivar & B & $\mathrm{Ba}$ & Co & $\mathrm{Cr}$ & $\mathrm{Cu}$ & $\mathrm{Fe}$ & $\mathrm{Mn}$ & $\mathrm{Ni}$ & $\mathrm{Se}$ & $\mathrm{Sr}$ & V & $\mathrm{Zn}$ & $\mathrm{Al}$ & As & $\mathrm{Pb}$ \\
\hline $\begin{array}{l}\text { Pink } \\
\text { Lady }\end{array}$ & $\begin{array}{c}2.597 \pm \\
0.081\end{array}$ & $\begin{array}{l}0.146 \pm \\
0.013\end{array}$ & $\begin{array}{l}0.002 \pm \\
0.000\end{array}$ & $\begin{array}{l}0.058 \pm \\
0.002\end{array}$ & $\begin{array}{l}0.509 \pm \\
0.010\end{array}$ & $\begin{array}{l}5.962 \pm \\
0.131\end{array}$ & $\begin{array}{l}0.815 \pm \\
0.012\end{array}$ & $\begin{array}{l}1.264 \pm \\
0.013\end{array}$ & $\begin{array}{l}0.009 \pm \\
0.000\end{array}$ & $\begin{array}{l}0.282 \pm \\
0.015\end{array}$ & $\begin{array}{l}1.183 \pm \\
0.052\end{array}$ & $\begin{array}{c}0.412 \pm \\
0.021\end{array}$ & $\begin{array}{l}3.236 \pm \\
0.099\end{array}$ & $\begin{array}{l}0.020 \pm \\
0.001\end{array}$ & $\begin{array}{l}0.016 \pm \\
0.002\end{array}$ \\
\hline $\begin{array}{c}\text { Red } \\
\text { Delicious }\end{array}$ & $\begin{array}{l}2.185 \pm \\
0.073\end{array}$ & $\begin{array}{l}0.075 \pm \\
0.059\end{array}$ & $\begin{array}{l}0.007 \pm \\
0.000\end{array}$ & $\begin{array}{l}0.055 \pm \\
0.002\end{array}$ & $\begin{array}{l}0.498 \pm \\
0.009\end{array}$ & $\begin{array}{l}6.031 \pm \\
0.141\end{array}$ & $\begin{array}{l}2.329 \pm \\
0.02\end{array}$ & $\begin{array}{l}1.190 \pm \\
0.011\end{array}$ & $\begin{array}{l}0.005 \pm \\
0.000\end{array}$ & $\begin{array}{l}0.531 \pm \\
0.019\end{array}$ & $\begin{array}{l}1.075 \pm \\
0.043\end{array}$ & $\begin{array}{c}0.385 \pm \\
0.022\end{array}$ & $\begin{array}{l}3.081 \pm \\
0.132\end{array}$ & $\begin{array}{l}0.025 \pm \\
0.002\end{array}$ & $\begin{array}{l}0.016 \pm \\
0.001\end{array}$ \\
\hline Idared & $\begin{array}{r}4.081 \\
0.102\end{array}$ & $\begin{array}{l}0.103 \pm \\
0.062\end{array}$ & $\begin{array}{l}0.006 \pm \\
0.000\end{array}$ & $\begin{array}{l}0.053 \pm \\
0.003\end{array}$ & $\begin{array}{c}0.625 \pm \\
0.011\end{array}$ & $\begin{array}{l}6.839 \pm \\
0.104\end{array}$ & $\begin{array}{l}2.709 \pm \\
0.023\end{array}$ & $\begin{array}{l}1.215 \pm \\
0.011\end{array}$ & $\begin{array}{l}0.005 \pm \\
0.000\end{array}$ & $\begin{array}{l}0.638 \pm \\
0.011\end{array}$ & $\begin{array}{l}1.193 \pm \\
0.053\end{array}$ & $\begin{array}{l}0.424 \pm \\
0.019\end{array}$ & $\begin{array}{l}3.586 \pm \\
0.153\end{array}$ & $\begin{array}{l}0.022 \pm \\
0.001\end{array}$ & $\begin{array}{l}0.020 \pm \\
0.003\end{array}$ \\
\hline Breburn & $\begin{array}{c}4.049 \pm \\
0.101\end{array}$ & $\begin{array}{l}0.186 \pm \\
0.015\end{array}$ & $\begin{array}{l}0.006 \pm \\
0.000\end{array}$ & $\begin{array}{l}0.052 \pm \\
0.002\end{array}$ & $\begin{array}{l}0.548 \pm \\
0.013\end{array}$ & $\begin{array}{l}7.363 \pm \\
0.152\end{array}$ & $\begin{array}{c}0.747 \pm \\
0.011\end{array}$ & $\begin{array}{l}1.294 \pm \\
0.011\end{array}$ & $\begin{array}{l}0.005 \pm \\
0.000\end{array}$ & $\begin{array}{c}0.213 \pm \\
0.01\end{array}$ & $\begin{array}{l}1.112 \pm \\
0.033\end{array}$ & $\begin{array}{l}0.349 \pm \\
0.026\end{array}$ & $\begin{array}{c}4.666 \pm \\
0.161\end{array}$ & $\begin{array}{l}0.024 \pm \\
0.002\end{array}$ & $\begin{array}{l}0.021 \pm \\
0.002\end{array}$ \\
\hline Modi & $\begin{array}{c}4.749 \pm \\
0.133\end{array}$ & $\begin{array}{l}0.191 \pm \\
0.021\end{array}$ & $\begin{array}{l}0.004 \pm \\
0.000\end{array}$ & $\begin{array}{l}0.059 \pm \\
0.003\end{array}$ & $\begin{array}{l}0.512 \pm \\
0.011\end{array}$ & $\begin{array}{l}6.794 \pm \\
0.133\end{array}$ & $\begin{array}{l}1.461 \pm \\
0.018\end{array}$ & $\begin{array}{l}1.437 \pm \\
0.011\end{array}$ & $\begin{array}{l}0.007 \pm \\
0.000\end{array}$ & $\begin{array}{c}0.254 \pm \\
0.012\end{array}$ & $\begin{array}{l}1.191 \pm \\
0.065\end{array}$ & $\begin{array}{l}0.398 \pm \\
0.021\end{array}$ & $\begin{array}{l}3.958 \pm \\
0.181\end{array}$ & $\begin{array}{l}0.019 \pm \\
0.001\end{array}$ & $\begin{array}{l}0.022 \pm \\
0.003\end{array}$ \\
\hline
\end{tabular}

Redox active elements (e.g., Fe and $\mathrm{Cu}$ ) may induce oxidative hazard and thereby contribute to pathogenesis of serious diseases [40]. Iron is a component of haemoglobin and various enzymes. A deficiency of Fe causes anaemia while the excess may increase the risk of developing cancer or a heart attack. Iron is present in both divalent and trivalent forms; the former is known to be readily absorbed [41]. The concentration of iron ranged from $5.962 \mathrm{mg}$ metal $\mathrm{kg}^{-1} \mathrm{f}$.w. to $7.363 \mathrm{mg}$ metal kg-11.w.

Copper is a component of enzymes required for $\mathrm{Fe}$ metabolism, its essentiality is mediated through specific copper proteins. The Cu deficiency leads to a high blood pressure and infertility [42].The concentration of copper in the apple peel samples resulted in $0.498 \mathrm{mgkg}^{-1} \mathrm{f}$.w. and $0.625 \mathrm{mgkg}^{-1} \mathrm{f}$.w.

It was found that the average contents of $\mathrm{Al}$, $\mathrm{Ba}$ and $V$ found in five varieties of the apple peel samples were $3.704,0.140,1.150$, respectively.

The recommended daily dose for $V$ is not set [43]. Its role in a diet is little known but seems to be very important. It is assumed that it affects the formation of insulin. Together with tin, $V$ is involved in the metabolism of fat and affects the proper functioning of the reproductive system and the production oftestosterone.

Selenium has been suggested as an active modulator in inflammatory and immune responses [44].The concentrations of Se were determined in the range 0.005$0.009 \mathrm{mg} \mathrm{kg}^{-1} \mathrm{f}$.w.

Manganese is one of the vital important elements. Manganese is both part of the structure of some enzymes and active to some enzymes. Manganese was detected in all apple peel samples and the concentration ranged from 0.747 to $2.709 \mathrm{mgkg}^{-1} \mathrm{f}$.w.

Strontium can be taken into the body by eating food or drinking water. Strontium bears a chemical resemblance to calcium and can displace it at times. Strontium can improve the cellular makeup of bones and teeth by preventing tooth decay or soft bones. It has not been proven that low strontium can cause the negative outcomes similar to calcium. The reference ranges determined in all apple peel samples ranged from 0.213in cv. 'Breburn' to $0.638 \mathrm{mgkg}^{-1} \mathrm{f}$.w. in cv. 'Idared'.No literature data were found for the comparison.

Zinc is essential for humans since it is a co-factor in enzymes, some of them being involved in the protection against oxidative processes. Also, $\mathrm{Zn}$ is used in treating shortness and other diseases and in fruit juice industries. The zinc contents in the apple samples ranged from $0.385 \mathrm{mgkg}^{-1} \mathrm{f}$.w. in cv. 'Red Delicious' to $0.424 \mathrm{mgkg}^{-1} \mathrm{f}$.w. in cv. 'Idared'.

Cobalt is the integral part of vitamin B12, the only metal-containing vitamin which includes a family of compounds which contain cobalamin and which show the same vitamin activity (cyanocobalamin, hydroxokobalamin, methylcobalamin and adenosylcobalamin) [45]. The concentrations of Co were determined in the range $0.002-0.007 \mathrm{mg} \mathrm{kg}^{-1}$ f.w. The knowledge concerning the bioavailability of vitamin B12 from various food sources is rather limited, despite its importance for human metabolism, the production of red blood cells and maintenance of the central nervous system.

Chromium ( $\mathrm{Cr}$ ) and cobalt (Co) are also essential for the metabolism of fats, carbohydrates and the synthesis of proteins. Whereas $\mathrm{Cr}(\mathrm{III})$ is required in trace amounts for sugar metabolism in humans, nickel (Ni) plays numerous roles in hormonal activity, lipid metabolism, activation of some enzymes and stabilisation of DNA and RNA $[46,47]$. However, the chronic exposure to $\mathrm{Cr}(\mathrm{VI})$ compounds can cause a permanent eyeinjury or allergic contact dermatitis. The concentration of $\mathrm{Cr}$ was determined in the range 0.052-0.059 $\mathrm{mg} \mathrm{kg}^{-1}$ f.w. According to IARC classification [48], $\mathrm{Cr}(\mathrm{VI})$ and $\mathrm{Ni}$ are established 
human carcinogens while an excessively high intake of Co may damage heartmuscles andmay cause an overproduction of red blood cells or a damage to the thyroid gland [43]. Our results for $\mathrm{Ni}$ are slightly higher than the results given by Ozcan et al., [49] (90.23-0.70 $\left.\mathrm{mgkg}^{-1}\right)$.

As known, same areas where there is a human activity have the heavy metal pollution due to different sources such as home wastes, straw and traffic wastes. Heavy metal includes the element with the atomic number greater than 20, excluding alkali metals, alkaline earths, lanthanides and actinides. The plants which grow affected by those pollutants can contain a different range of heavy metals. Also, the aim of this study is the determination of cadmium, nickel and lead content of the apple cultivars which were produced in Southeastern Serbia and the investigation of the potential health risks for humans [50].

Cadmium was not detected on the fruit tissues evaluated. Heavy metals such as $\mathrm{Ni}, \mathrm{Pb}$ and $\mathrm{Cd}$ not only affect the nutritive values of fruits and vegetables, but also have deleterious effects on the human health because they can,for example cause mental retardation and semi-permanent brain damage or dysfunction in the lungs, liver, bone or kidneys [51].

Trichopoulos [52] reported that $\mathrm{Pb}$ has a toxic effect for human metabolism even in low amounts and may havecarcinogenic effects. The concentration of $\mathrm{Pb}$ was determined in the range $0.016-0.022 \mathrm{mg} \mathrm{kg}^{-1} \mathrm{f} . \mathrm{w}$.

The results of the heavy metal concentrations were compared with the values recommended by the World Health Organization [43] and EU Directives [53] for fruits. Based on the WHO health criteria and EU Directive (milligrams per kilogram wet weight) for $\mathrm{Pb}(0.1-1.0)$, $\mathrm{Cd}$ (0.05), $\mathrm{Cr}(0.03)$, Ni (0.5), and $\mathrm{Cu}(0.2-1.2)$, there are no health risks with respect to the concentrations of lead, nickel, copper, cadmium, and chromium in fruits and wines analyzed in this study.

The comparison of Serbian apple peel samples with the samples from other regions, regarding mineral levels, is given in Table 5. For many elements, no literature data were found for the content in the apple peel converted to the fresh weight of fruit. It can be seen that our results are in line with all listed in Table 5, except for the samples from Nigeria.

Table 5. The comparison of Serbian apple peel samples with those from other regions regarding mineral levels ( $\mathrm{mgkg}^{-1}$ f.w.).

\begin{tabular}{cccccccccc}
\hline $\begin{array}{c}\text { Grown } \\
\text { region }\end{array}$ & $\mathrm{Na}$ & $\mathrm{K}$ & $\mathrm{Ca}$ & $\mathrm{Mg}$ & $\mathrm{Fe}$ & $\mathrm{Mn}$ & $\mathrm{Cu}$ & $\mathrm{Zn}$ & Reference \\
\hline Serbia & 128.058 & 1516.13 & 173.33 & 110.01 & 6.598 & 1.612 & 0.538 & 0.394 & Current \\
Chile & $70-130$ & $115-1365$ & $98-179$ & $219-255$ & $8.4-9.9$ & $1.4-3.9$ & $0.8-1.5$ & $0.5-1.3$ & {$[39]$} \\
Lebanon & $/$ & $/$ & $/$ & $/$ & 3.7 & 0.82 & 1.2 & 0.47 & {$[54]$} \\
Israel & 48 & 1070 & 91.5 & 126 & 2.87 & 0.715 & 0.471 & 0.402 & {$[21]$} \\
Nigeria & 43.858 & 62.26 & 8.251 & 6.162 & 37.330 & $/$ & $/$ & 13.46 & {$[55]$} \\
\hline
\end{tabular}

For better illustration, PCA was conducted to evaluate the metal content in the apple peel samples.Based on the data obtained from the determination of the selected elements in apples (Tables 3 and 4), PCA was used for possible differences of the apple samples. PCA is a useful tool, because one of its advantages is the reduction of the number of variables of the experimental data and the extraction of a small number of latent factors (principal components, PCAs) for analyzing the relationships among the observed variables [30, 31]. According to suchplot, it is possible to classify the samples by their element distribution. The starting point for the PCA calculations was the matrix of data with dimensions $\mathrm{n} \times \mathrm{p}$, where $\mathrm{n}$ is the number of cases (rows) and $\mathrm{p}$ is the number of variables (columns). In the matrix, apple samples (Pink lady, Red delicious, Idared, Breburn and Modi) were used as rows. Columns were the results of the selected elements analysis of the apple samples. As a result of PCA analysis, 20 new variables were obtained which were characterized by consecutive eigenvalues. Performed statistics with Pearson correlation matrix on the apple samples based on the selected elements content shows that there is a strong positive correla- tion between the quantity of aluminum and iron (0.935), lead and boron (0.990), manganese and barium (0.945), phosphorus and barium (0.919), strontium and barium (0.971), vanadium and magnesium (1.000), strontium and manganese (0.945), strontium and phosphorus (0.919), and a strong negative correlation between the quantity of arsenic and magnesium (-0.894), arsenic and vanadium (-0.893), selenium and cobalt $(-0.978)$, nickel and iron (-0.881), phosphorus and sodium (-0.894).

The number of factors represents the total number of variables used in the dataset. Eigenvalues for the first four factors are higher $(7.422,5.896,5.441$ and 1.241, respectively) compared to the values for the rest of the factors. So, four factors must be used to explain the obtained variabilities $(37.11 \%, 29.48 \%, 27.20 \%$ and $6.20 \%$ ) 


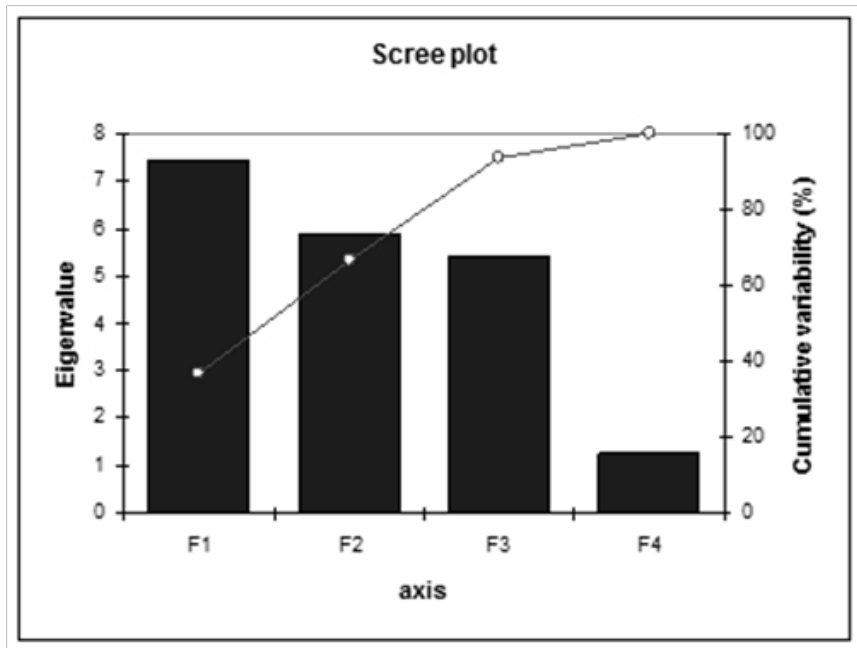

Figure 1. Plot shows the importance of the factors and values of cumulative variabilities. Some values for factors (F1, F2, F3 and F4) are positive and some of them are negative.

Observation plots based on the content of selected elements are represented in Figure 2. From Figure 2a., it is visible that a high content of aluminum is present in the apple samples on the right side of the plot and low on the left side of the plot. Also, it can be concluded that a high content of arsenic is present in the apple samples in the upper half of the plot and low on the opposite side of the plot. Similarly, Figure $2 b$ shows a high content of arsenic on the right side of the plot and low on the left side of the plot. A high content of boron is present in the apple samples in the upper half of the plot and low on the opposite side of the plot. Figure $2 \mathrm{c}$ confirms the information onthe low and high quantity of boron, but it also shows the quantity of barium; a high content of barium is present in the apple samples in the upper half of the plot and low on the opposite side of the plot.

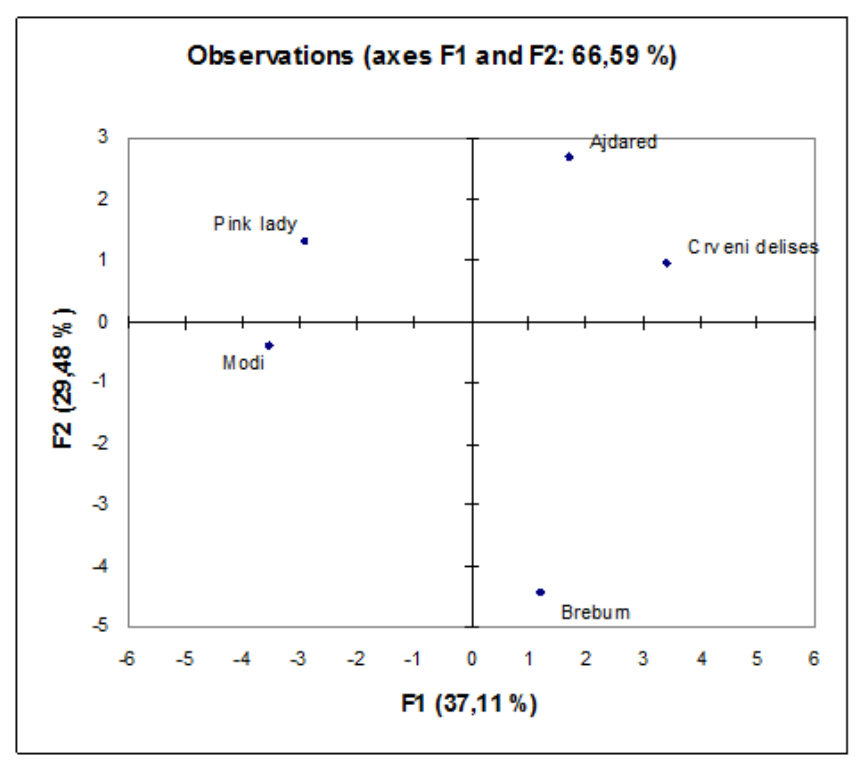

a)

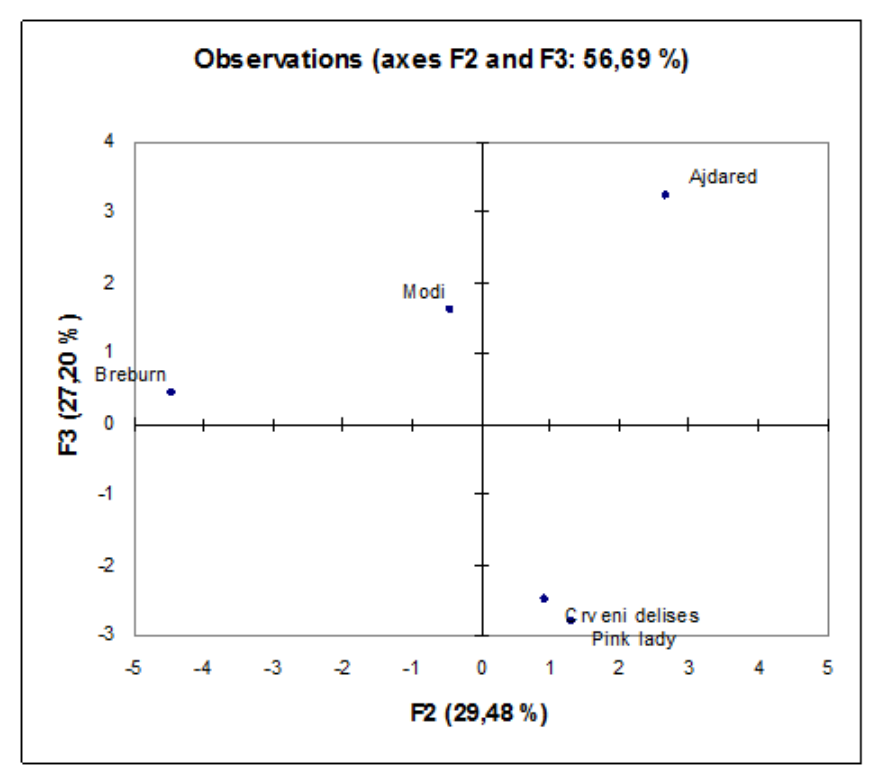

b)

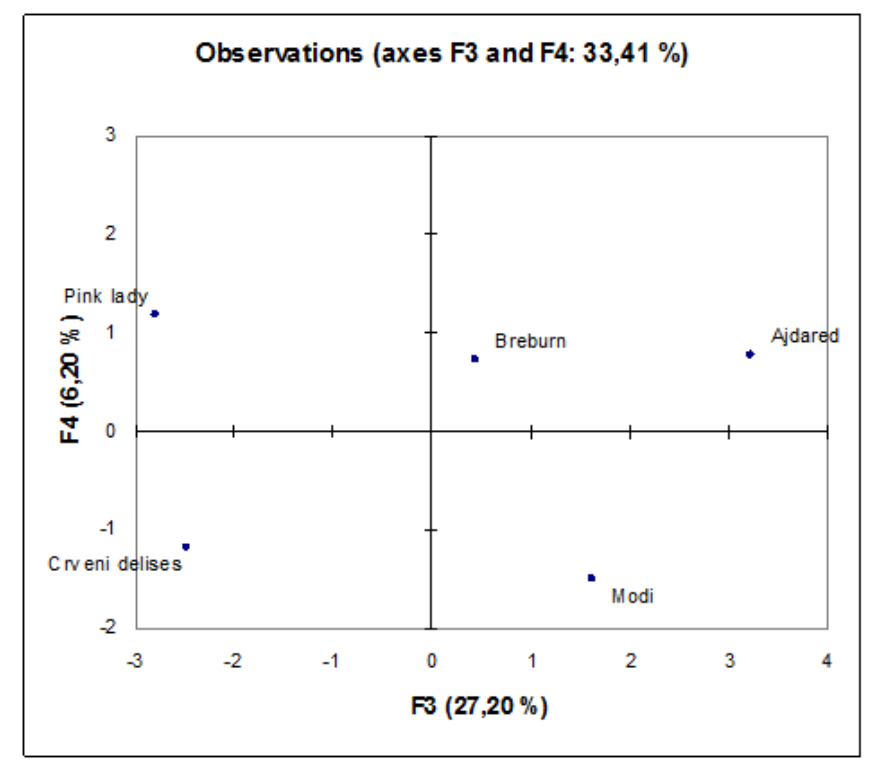

c)

Figure 2. Principal component score plots a) (F1 and F2), b) (F2 and F3), and c) (F3 and F4) of the studied plant samples based on the content of selected elements.

\section{Conclusion}

ICP-OES method was successfully applied to determine multi-elements in the peel of five apple cultivars grown in Southeastern Serbia. Since the measurement of intakes of various elements by man is of importance in nutrition, the results obtained can therefore be useful information with respect to their minerals consumption.

The present investigation indicates that ICP-OES technique is suitable for the determination of the content of 21 elements in the apple samples. The concentrations of elements in various apple cultivars were different. The 
analytical values obtained for the analyzed metals were in good agreement with those reported by other researchers. The levels of heavy metals in the apple peel samples were assessed by comparing the levels found in the samples with the requirements of $\mathrm{WHO}$ and EU Directives. The results obtained from this study show that there are no health risks from the consumption of apples when compared with the levels stipulated by health authorities.

\section{Acknowledgements}

This work was supported by the Serbian Ministry of Education and Science Protection (grant number 172047).

\section{References}

[1] J. Lampe, Health effects of vegetables and fruits: Assessing mechanisms of action in human experimental studies, American Journal of Clinical Nutrition, 70 (1999) 475-490.

[2] I. Arts, P. Hollman, Polyphenols and disease risk in epidemiologic studies, American Journal of Clinical Nutrition, 81 (2005) 317-325.

[3] S. Gorinstein, Z. Zachwieja, M. Folta, H. Barton, J. Piotrowicz, M. Zemser, Comparative contents of dietary fiber, total phenolics, and minerals in persimmons and apples, Journal of Agricultural and Food Chemistry, 49 (2001) 952-957

[4] D. Bakircioglu, Y. B. Kurtulus, G. Ucar, Determination of some trace metal levels in cheese samples packaged in plastic and tin containers by ICP-OES after dry, wet and microwave digestion, Food and Chemical Toxicology, 49 (2011) 202-207.

[5] M. Hamurcu, M. M. Ozcan, N. Dursun, S. Gezgin, Mineral and heavy metal levels of some fruits grown at the roadsides, Food and Chemical Toxicology, 48 (2010) 1767-1770.

[6] F. Ismail, M. R. Anjum, A. N. Mamon, T. G. Kazi, Trace metal contents of vegetables and fruits of Hyderabad retail market, Pakistan Journal of Nutrition, 10(4) (2011) 365-372.

[7] O. Reykdal, S. Rabieh, L. Steingrimsdottir, H. Gunnlaugsdottir, Minerals and trace elements in Icelandic dairy products and meat, Journal of Food Composition and Analysis, 24 (2011) 980-986.

[8] B. D'Abrosca, S. Pacifico, G. Cefarelli, C. Mastellone, A. Fiorentino,'Limoncella' apple, an Italian apple cultivar: Phenolic and flavonoid contents and antioxidant activity, Food Chemistry, 104 (2007) 1333-1337.

[9] M. Battino, J. Beekwilder, B. Denoyes-Rothan, M. Laimer G. J. McDougall, B. Mezzetti, Bioactive compounds in berries relevant to human health, Nutrition Reviews, 67 (2009) 145-150.

[10] M. R. Alberto, M. A. Rinsdahl-Canavosio, M. C. Manca de Nadra, Antimicrobial effect of polyphenols from apple skins on human bacterial pathogens, Electronic Journal of Biotechnology, 9 (2006) 205-209.

[11] J. Wu, H. Gao, L. Zhao, X. Liao, F. Chen, Z. Wang, X. Hu, Chemical compositional characterization of some apple cultivars, Food Chemistry, 103 (2007) 88-93.

[12] K. L. Wolfe, R. H. Liu, Apple peels as a value-added food ingredient, Journal of Agricultural and Food Chemistry, 51 (2003) 1676-1683.

[13] J. Boyer, R. H. Liu, Apple phytochemicals and their health benefits, Nutrition Journal 3 (5) (2004) 1-15.

[14] X. He, R. H. Liu, Triterpenoids isolated from apple peels have potent anti-proliferative activity and may be partially responsible for apple's anticancer activity, Journal of Agricultural and Food Chemistry, 55 (2007) 4366-4370.

[15] M. Leontowicz, S. Gorinstein, H. Leontowicz, R. Krzeminski, A. Lojek, E. Katrich, M. Čiž, O. Martin-Belloso, R. SolivaFortuny, R. Haruenkit, S. Trakhtenberg, Apple and pear peel and pulp and their influence on plasma lipids and antioxidant potentials in rats fed cholesterol-containing diets, Journal of Agricultural and Food Chemistry, 51 (2003) 5780-5785.

[16] B. Lata, Relationship between apple peel and the whole fruit antioxidant content: Year and cultivar variation, Journal of Agricultural and Food Chemistry, 55 (2007) 663-671.

[17] J. Scalzo, A. Politi, N. Pellegrini, B. Mezzetti, M. Battino, Plant genotype affects total antioxidant capacity and phenolic contents in fruit, Nutrition, 21(2) (2005) 207-213.

[18] J. J. Mangas, R. Rodriguez, B. Suarez, A. Picinelli, E. Dapena, Study of the phenolic profile of cider apple cultivars at maturity by multivariate techniques, Journal of Agricultural and Food Chemistry, 47(10) (1999) 40464052 .

[19] A. Podesedec, J. Wilska-Jeszka, B. Anders, J. Markowski, Compositional characterization of some apple varieties, European Food Research and Technology, 210 (2000) 268-272.

[20] M. Manzoor, F. Anwar, N. Saari, M. Ashraf, Variations of antioxidant characteristics and mineral contents in pulp and peel of different apple (MalusdomesticaBorkh.) cultivars from Pakistan, Molecules, 17 (2012) 390-407.

[21] S. Gorinstein, Z. Zachwieja, M. Folta, H. Barton, J. Piotrowicz, M. Zemser, M. Weisz, S. Trakhtenberg, O. Martın-Belloso, Comparative contents of dietary fiber, total phenolics, and minerals in persimmons and apples, Journal of Agricultural and Food Chemistry, 49 (2001) 952-957.

[22] K. Bakkali, N. R. Martos, B. Souhail, E. Ballesteros, Characterization of trace metals in vegetables by graphite furnace atomic absorption spectrometry after closed vessel microwave digestion, Food Chemistry, 116 (2009) 590-594.

[23] C. Ekinci, U. Koklu, Determination of vanadium, manganese, silver and lead by graphite furnace atomic absorption spectrometry after preconcentration on silica-gel modified with 3-aminopropyltriethoxysilane, SpectrochimicaActa Part B, 55 (2000)1491-1495.

[24] B. Mikuła, and B. Puzio, Determination of trace metals by ICP-OES in plant materials after preconcentration of 1,10-phenanthroline complexes on activated carbon, Talanta, 71 (2007) 136-140.

[25] F. S. Fallah, S. S. Saei-Dehkordi, A. Nematollahi, T. Jafari, Comparative study of heavy metal and trace element accumulation in edible tissues of farmed and wild rainbow trout (Oncorhynchusmykiss) using ICP-OES technique, Microchemical Journal, 98 (2011) 275-279.

[26] I. Jaric, Z. Visnjic-Jeftic, G. Cvijanovic, Z. Gacic, L. Jovanovic, S. Skoric, M. Lenhardt, Determination of differential heavy metal and trace element accumulation in liver, gills, intestine and muscle of sterlet(Acipenserruthenus) from 
the Danube River in Serbia by ICP-OES, Microchemical Journal, 98 (2011) 77-81.

[27] S. S. Mitic, M. V. Obradovic, M. N. Mitic, D. A. Kostic., A. N. Pavlovic, S. B. Tosic, M. D. Stojkovic, Elemental composition of various sour cherry and table grape cultivars using inductively coupled plasma atomic emission spectrometry method (ICP-OES), Food Analytical Methods, 5 (2012) 279-286.

[28] R. E. S. Froes, W. B. Neto, N. O. C. e Silva, R. L. P. Naveira, C. C. Nascentes, J. B. B. da Silva, Multivariate optimization by exploratory analysis applied to the determination of microelements in fruit juice by inductively coupled plasma optical emission spectrometry, SpectrochimicaActa Part B: Atomic Spectroscopy, 64 (2009) 619-622.

[29] P.W.J.M. Boumans, Line Coincidence Tables for Inductively Coupled Plasma Atomic Emission Spectrometry, 2nd Edition. Pergamon Press, Oxford, United Kingdom, 1984.

[30] J. D. Horel,A rotated principal component analysis of the interannual variability of the Northern Hemisphere 500 mb height field,Monthly Weather Review, 109 (10) (1981) 2080-2092.

[31] J. D. Horel, Complex principal component analysis: Theory and examples, Journal of climate and Applied Meteorology, 23 (12) (1984) 1660-1673.

[32] H. Greenfield, D. A. T. Southgate, Food composition data - production, management and use, London: Elsevier Applied Science, 1992.

[33] I. Torelm, R. Danielsson, Variations in major nutrients and minerals in Swedish foods: a multivariate, multifactorial approach to the effects of season, region and chain, Journal of Food Composition and Analysis, 11 (1998) 1131.

[34] R. Macrae, R. K. Robinson, M. J. Sadler, Encyclopaedia of food science, food technology and nutrition (Vol. 5), San Diego, CA: Academic press Inc., 1993, p. 4593-4600.

[35] J. M. deMan, The principles of food chemistry (3rd ed.), Gaithersburg: Aspen Publishers, 1999.

[36] R. Segura, C. Javierre, M. A. Lizarraga, E. Ros, Other relevant components of nuts: phytosterols, folate and minerals, British Journal of Nutrition, 96(2) (2006) 36-44.

[37] S. T. de Freitas, C. V. T. do Amarante, J. M. Labavitch, E. J. Mitcham, Cellular approach to understand bitter pit development in apple fruit, Postharvest Biology and Technology, 57(1) (2010) 6-13.

[38] A. Duran, M. Tuzen, M. Soylak, Trace element levels in some dried fruit samples from Turkey, International Journal of Food Sciences and Nutrition, 59 (2008) 581589.

[39] C. Henríquez, S. Almonacid, I. Chiffelle, T. Valenzuela, M. Araya, L. Cabezas, R. Simpson, H. Speisky, Determination of Antioxidant Capacity, Total Phenolic Content and Mineral Composition of Different Fruit Tissue of Five Apple Cultivars Grown in Chile, Chilean Journal of Agricultural Research 70(4) (2010) 523-536.

[40] A.I. Bush, Metal complexing agents as therapies for Alzheimer's disease, Neurobiology Aging, 23 (2002) 1031-1038.

[41] S. Hemalatha, K. Platel, K. Srinivasan, Zinc and iron contents and their bioaccessibility in cereals and pulses consumed in India, Food Chemistry, 102 (2007) 13281336.

[42] D. Vitali, I. VedrinaDragojevic, B. Sebecic, Food Chemistry, Bioaccessibility of $\mathrm{Ca}, \mathrm{Mg}, \mathrm{Mn}$ and $\mathrm{Cu}$ from whole grain tea-biscuits: Impact of proteins, phytic acid and polyphenols, 110 (2008) 62-68.

[43] World Health Organization (WHO). Evaluation of certain food additives and contaminants. Technical report series, No. 837, World Health Organization, Geneva, 1993.

[44] J. Neve, Physiological and nutritional importance of selenium, Experiential, 47 (1991) 187-193.

[45] J. Lindemans, in: A.P. De Leenheer, W.E. Lambert, I.F. Van Bocxlaer (Eds.), Modern Chromatographic Analysis of Vitamins, Marcel Dekker, New York, 2000.

[46] M. Grembecka, P. Szefer, Metals and metalloids in foods: essentiality, toxicity, applicability, inD.A.Medina\& A. M. Laine (Eds.), Food quality: control, analysis and consumer concerns Hauppauge: Nova Science Publishers, 2011, p. $1-60$.

[47] M. Nabrzyski, Functional role of some minerals in foods. In P. Szefer\& J. O. Nriagu (Eds.), Mineral components in foods, London: CRC Press, 2007, p. 363-388.

[48] IARC Monographs, Arsenic, metals, fibres and dusts. Volume 100C.A review of human carcinogens.http:// monographs.iarc.fr/ENG/Monographs/vol100C/ mono100C.pdf.Accessed 5th March 2013.

[49] M. M. Özcan, M. Harmankaya, S. Gezgin, Mineral and heavy metal contents of the outer and inner tissues of commonly used fruits, Environ Monit Assess, 184 (2012) 313-320.

[50] S. S. Mitic, A. N. Pavlovic, S. S. Tosic, B. T. Stojanovic, M. N. Mitic, M. LJ. Stojkovic, Elemental composition of various apple cultivars grown in Serbia, Asian Journal of Chemistry, 25 (11) (2013) 6027-6032.

[51] A. Duran, M. Tuzen, M. Soylak, Trace element levels in some dried fruit samples from Turkey, International Journal of Food Sciences and Nutrition, 59 (2008) 581 589.

[52] D. Trichopoulos, Epidemiology of cancer, in: DeVita, V. T. (Ed): Cancer: principles and practice of oncology, Philadelphia: Lippincott, 1997, p. 235-239.

[53] Commission of the European Communities: Commission Regulation (EC) No.221/2002 of the 6 February 2002 amending regulation (EC) No. 466/2002 setting maximum levels for certain contaminants in foodstuffs. Official Journal of the European Communities, Brussels, 2002.

[54] R. B. Khouzama, P. Pohlb, R. Lobinski, Bioaccessibility of essential elements from white cheese, bread, fruit and vegetables, Talanta 86 (2011) 425-428.

[55] U. D. Akpabio, A. E. Akpakpan, G. N. Enin, Evaluation of proximate compositions and mineral elements in the star apple peel, pulp and seed, Journal of Basic and Applied Scientific Research, 2(5) (2012) 4839-4843. 
Izvod

\section{MULTIELEMENTNA ANALIZA KORE JABUKA PRIMENOM ICP-OES METODE}

Branka T. Stojanović, Snežana S. Mitić, Milan N. Mitić, Dušan Đ. Paunović, Biljana B. Arsić, Gordana S. Stojanović

U radu je određen sadržaj 21 elemenata u kori pet sorti jabuka pomoću optičke emisione spektometrije sa indukovano spregnutom plazmom. Od makroelemenata $\mathrm{u}$ ispitivanim uzorcima kore jabuka najzastupljeniji je $\mathrm{K}$, a nakon toga, $\mathrm{P}, \mathrm{Ca}$, Mg i Na. Od mikroelemenata najzastupljeniji su Fe, B, Mn, V, Cu, Zn. U pogledu sadržaja teških metala, može se zaključiti da su koncentracije $\mathrm{As}, \mathrm{Cd}, \mathrm{Ni}$ i Pb ispod maksimalno dozvoljenih koncentracija, propisanih domaćom zakonskom regulativom i EU propisima. Dobijeni rezultati pokazuju da ne postoje zdravstveni rizici od konzumiranja jabuka kada se uporede sa propisanim od strane zdravstvenih vlasti. Analiza glavnih komponenta je primenjena za klasifikaciju analiziranih elemenata u kori pet sorti jabuka u skladu sa njihovim sadržajem.
Ključne reči: minerali, kora jabuke, ICP-OES, PCA 